\title{
FAKTOR - FAKTOR YANG BERHUBUNGAN DENGAN KETERAMPILAN CUCI TANGAN PADA ANAK KELAS IV DAN V DI SDN 179 KECAMATAN RUMBAI KOTA PEKANBARU
}

\author{
Oldhi Hanafi ${ }^{1}$, Siska Mayang Sari ${ }^{2}$, Abdurrahman Hamid ${ }^{3}$ \\ ${ }^{1,2,3}$ Program Studi Ilmu Keperawatan Sekolah Tinggi Ilmu Kesehatan (STIKes) Hang Tuah \\ J1. Mustafa Sari No. 5 Tangkerang Selatan Pekanbaru, Riau - 28000. \\ E-mail: Oldhyhanafi11@gmail.com
}

\begin{abstract}
Abstrak
Mencuci tangan dengan menggunakan sabun adalah salah satu cara untuk membiasakan anak-anak untuk memiliki gaya hidup bersih yang sehat. Akan tetapi masih banyak orang tua yang masih belum mengajarkan anak-anaknya bagaimana pentingnya mencuci tangan. Penelitian ini bertujuan mengetahui faktor-faktor yang berhubungan dengan keterampilan cuci tangan pada anak kelas IV dan V SDN 179 Kecamatan Rumbai Kota Pekanbaru. Penelitian ini merupakan penelitian kuantitatif menggunakan desain korelasi dengan pendekatan cross sectional. Populasi pada penelitian ini adalah siswa/siswi kelas IV dan V SDN 179 Kota Pekanbaru. Sampel pada penelitian ini berjumlah 40 yang diambil dengan teknik stratified random sampling. Penelitian Instrumen penelitian berupa kuesioner dengan 24 pertanyaan. Analisis data menggunakan uji bivariat chisquare dan fisher exact. Penelitian ini dilakukan pada bulan Agustus tahun 2018. Hasil penelitian peran guru berhubungan dengan keterampilan cuci tangan dengan $P_{\text {value }}=0,029$ sementara itu dukungan teman sebaya, peran orang tua, dan peran petugas kesehatan tidak berhubungan keterampilan cuci tangan pada anak ( $P_{\text {value }}$ $>0,05)$. Diharapkan kepada pihak guru untuk meningkatkan kukungan kepada anak dalam meningkatkan keterampilan cuci tangan pada anak di sekolah.
\end{abstract}

Kata kunci : Dukungan teman sebaya, peran orang tua, peran petugas kesehatan, peran guru, keterampilan mencuci tangan pada anak.

\begin{abstract}
Hand washing by using soap is one of the way to habituate the children to having a healthy clean lifestyle. But, there are many parents still not training their children about hand washing. This research purpose was to knew the related factors with hand washing skills in children in $4^{\text {th }}$ and $5^{\text {th }}$ grade of SDN 179 in Rumbai Subdistrict, Pekanbaru. This was a quantitative study by using a correlation design with cross sectional approach. The population were students in $4^{\text {th }}$ and $5^{\text {th }}$ grade of SDN 179 Rumbai Subdistrict, Pekanbaru. The sample were 40 which taken by stratified random sampling. The instrument was used questionnaire with 24 questions and data analyzed used bivariate with chi-square test and fisher exact. The result showed that teacher's role related to children hand washing skill's $P$ value $=0.029$. Meanwhile, peers support, parent's role, and health officer role were not related to children hand washing skill's ( $P$ value $>0.05)$. It is recommended to the teacher to improving their support to children in order to children hand washing skill's in their school.
\end{abstract}

Keywords : Peers support, parents role, health officer role, teachers role, children hand washing skills.

\section{PENDAHULUAN}

Perilaku Hidup Bersih dan Sehat (PHBS) adalah suatu contoh pola hidup keluarga yang selalu mempertahankan dan menjaga kesehatan seluruh anggota keluarganya. Semua perilaku mengenai kesehatan yang dilakukan dari dalam diri masing - masing anggota keluarga sehingga setiap anggota dapat menolong dirinya pada masalah kesehatan dan berperan aktif dalam kegiatan kesehatan di masyarakat (Proverawati \& Rahmawati, 2012). 
Oldhi Hanafi, Siska Mayang Sari, Abdurrahman Hamid,Faktor - Faktor yang Berhubungan dengan Keterampilan Cuci Tangan pada Anak Kelas IV dan V di SDN 179 Kecamatan Rumbai Kota Pekanbaru

Cuci Tangan Pakai Sabun (CTPS) merupakan cara mudah dan tidak membutuhkan biaya dan tenaga yang berlebih, oleh karena itu perilaku mengajarkan atau membiasakan anak dan setiap anggota keluarga untuk mencuci tangan pakai sabun untuk mencapai keluarga yang hidup sehat sejak dini. Sikap yang membiasakan anak dari dini akan menanamkan perilaku hidup bersih dan sehat pada diri pribadi anak dan anggota keluarga yang lain. Cuci tangan pakai sabun adalah perilaku yang paling mudah dan dapat dimulai dari diri sendiri (Proverawati \& Rahmawati, 2012).

Berdasarkan World Health Organization tahun 2009 menjelaskan bahwa 1000 orang meninggal dunia setiap hari di seluruh dunia karena infeksi yang didapat. Cara masuk infeksi melalui pencernaan disebabkan oleh tangan. Tangan adalah jalan utama dari transmisi kuman, karena itu mencuci tangan adalah salah satu hal yang paling penting dilakukan untuk menghindari serangan kuman dan mecegah infeksi.

Berdasarkan Laporan Kinerja Kementrian Kesehatan Tahun 2016 yaitu grafik capaian Kabupaten Kota yang memiliki kebijakan PHBS per-Provinsi tahun 2016 yang terbanyak adalah Jawa Tengah. Provinsi ini memiliki 35 Kabupaten dan yang telah memiliki kebijakan PHBS adalah 31 Kabupaten atau Kota. Riau termasuk urutan yang memiliki capaian rendah karena dari 12
Kabupaten atau Kota hanya 5 Kabupaten yang memiliki kebijakan PHBS.

Berdasarkan laporan PHBS dari Dinas Kesehatan Kota Pekanbaru tahun 2017 yang dipantau melalui jumlah RT di Kota Pekanbaru menunjukkan angka ber-PHBS tertinggi yaitu Kecamatan Lima Puluh sebanyak $73,59 \%$ dan yang terendah terdapat pada Kecamatan Marpoyan Damai di Puskesmas Garuda sebanyak 21,42\%. Sedangkan angka Cuci tangan pakai sabun (CTPS) yang tertinggi terdapat pada Kecematan Sail yaitu sebanyak 89,88\% dan angka yang terendah terdapat pada Kecamatan Rumbai Bukit yaitu sebanyak 43,78\%.

Anak sekolah merupakan generasi penerus bangsa yang harus dijaga dan dilindungi kesehatannya. Jumlah anak usia sekolah di Indonesia cukup besar yaitu 30\% dari jumlah penduduk Indonesia dan pada usia sekolah inilah merupakan masa keemasan untuk menanamkan perilaku hidup bersih dan sehat sehigga anak sekolah berpotensi dalam perubahan sekaligus mempromosikan pola hidup sehat (PHBS), baik dilingkungan sekolah, keluarga, maupun masyarakat sekitar (Proverawati \& Rahmawati, 2012).

Menurut penetilian Nugroho dan Fajriyah (2014) tentang faktor yang berhubungan dengan penerapan cuci tangan pakai sabun pada murid kelas III dan IV SD Negeri 21 Talang Kelapa Kabupaten Banyuasin menjelaskan bahwa faktor yang mempengaruhi penerapan cuci tangan pakai 
sabun faktor pengetahuan, sikap, ketersediaan sarana CTPS, peran orang tua dan teman sebaya didapatkan hasil ada hubungan yang bermakna antara pengetahuan terhadap penerapan cuci tangan pakai sabun. Terdapat hubungan yang bermakna antara sikap terhadap penerapan cuci tangan pakai sabun. Terdapat hubungan yang bermakna antara ketersediaan sarana CTPS terhadap penerapan cuci tangan pakai sabun.

Berdasarkan penelitian Murwanto (2017) menjelaskan bahwa Perilaku Cuci Tangan Pakai Sabun (CTPS) di SMP sudah cukup baik (mencapai 55,9\%), sedangkan berdasarkan faktor yang mempengaruhi Sembilan variabel bernilai positif (pengetahuan, citra diri, nilainilai, kepercayaan, ketersedian tempat CTPS, kemudahan mendapatkan CTPS, peran guru, peran orang tua dan peran teman sekolah) dan terdapat tiga variabel yang bernilai negatif sebanyak 50\%, yaitu variabel sikap, persepsi dan peran petugas kesehatan.

Berdasarkan faktor - faktor dan data yang diperoleh dari Dinas Kesehatan Kota Pekanbaru yaitu cuci tangan pakai sabun pada Kecamatan Rumbai Bukit yaitu sebanyak 43,78\% ini membuktikan masih kurangnya kesadaran diri individu untuk pentingnya mencuci tangan dengan menggunakan sabun. Lingkungan yang berada di sekitar sekolah terlihat kumuh karena di samping sekolah terdapat tempat penumpukan barang-barang bekas. Pada lingkungan sekolah belum tersedia sarana mencuci tangan dan terlihat masih rendahnya keinginan untuk mencuci tangan. Berdasarkan penjelasan diatas peneliti tertarik untuk meneliti faktor-faktor yang berhubungan dengan keterampilan cuci tangan pada anak kelas IV dan V SDN 179 Kecamatan Rumbai Kota Pekanbaru.

\section{METODE PENELITIAN}

penelitian ini menggunakan korelasi dengan pendekatan cross sectional. Populasi pada penelitian ini adalah siswa/siswi kelas IV dan V SDN 179 Kota Pekanbaru. Sampel pada penelitian ini berjumlah 40 yang diambil dengan teknik stratified random sampling. Uji statistik menggunakan uji chi-square dan fhiser exact. Alat pengumpulan data menggunakan kuisioner yang dilakukan pada bulan Agustus tahun 2018.

\section{HASIL PENELITIAN}

\section{Analisa Univariat}

Tabel 1.

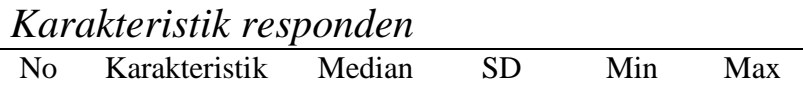

\begin{tabular}{llllll}
\hline 1 & Usia & 10,00 & 0,853 & 9 & 12
\end{tabular}

Berdasarkan karakteristik usia yang dipaparkan dapat disimpulkan bahwa nilai tengah usia responden (median) berusia 10 tahun. Rentang usia 9-12 adalah rentang usia yang ada di sekolah dasar Negeri 179 Kota Pekanbaru. 
Oldhi Hanafi, Siska Mayang Sari, Abdurrahman Hamid,Faktor - Faktor yang Berhubungan dengan Keterampilan Cuci Tangan pada Anak Kelas IV dan V di SDN 179 Kecamatan Rumbai Kota Pekanbaru

Tabel 2.

Jenis kelamin responden

\begin{tabular}{|c|c|c|}
\hline Variabel & $n$ & $\%$ \\
\hline \multicolumn{3}{|l|}{ Jenis kelamin } \\
\hline a. Perempuan & 22 & 55,0 \\
\hline b. Laki-laki & 18 & 45,0 \\
\hline Jumlah & 40 & 100,0 \\
\hline
\end{tabular}

Pada tabel di atas diperoleh bahwa mayoritas responden berjenis kelamin perempuan yaitu sebanyak $22 \quad(55,0 \%)$ responden.

Tabel 3.

Faktor-faktor yang berhubungan dengan keterampilan cuci tangan

\begin{tabular}{|c|c|c|c|}
\hline No & Variabel & $n$ & $\%$ \\
\hline 1. & $\begin{array}{l}\text { Dukungan teman } \\
\text { sebaya } \\
\text { a. Tinggi } \\
\text { b. Rendah }\end{array}$ & 27 & 32,5 \\
\hline 2. & $\begin{array}{l}\text { Peran guru } \\
\text { a. Tinggi } \\
\text { b. Rendah }\end{array}$ & $\begin{array}{l}34 \\
6\end{array}$ & $\begin{array}{l}85,0 \\
15,0\end{array}$ \\
\hline 3. & $\begin{array}{l}\text { Peran petugas } \\
\text { kesehatan } \\
\text { a. Tinggi } \\
\text { b. Rendah }\end{array}$ & 17 & $\begin{array}{l}57.5 \\
42,5\end{array}$ \\
\hline 4. & $\begin{array}{l}\text { Peran orang tua } \\
\text { a. Tinggi } \\
\text { b. Rendah }\end{array}$ & $\begin{array}{l}31 \\
9\end{array}$ & $\begin{array}{l}77,5 \\
22,5\end{array}$ \\
\hline 5. & $\begin{array}{l}\text { Keterampilan mecuci } \\
\text { tangan } \\
\text { a. Terampil } \\
\text { b. Tidak terampil } \\
\quad \text { Jumlah }\end{array}$ & $\begin{array}{l}24 \\
16 \\
40\end{array}$ & $\begin{array}{l}60,0 \\
40,0 \\
100,0\end{array}$ \\
\hline
\end{tabular}

Tabel 3 menjelaskan distribusi frekuensi responden berdasarkan faktor-faktor yang berhubungan dengan keterampilan cuci tangan yang tertinggi dukungan teman sebaya pada ketegori tinggi yaitu sebanyak $27(67,5 \%)$ responden, peran guru kategori tinggi yaitu sebanyak $34(85,5 \%)$ responden, peran petugas kesehatan kategori tinggi yaitu sebanyak 23
$(57,5 \%)$ responden, peran orang tua kategori tinggi yaitu sebanyak 31 (77,5\%) responden, keterampilan cuci tangan kategori terampil yaitu sebanyak $24(60,0 \%)$ responden.

\section{Analisa bivariat}

Tabel 4

Hubungan dukungan teman sebaya, peran guru, peran petugas kesehatan, peran orang tua dengan keterampilan mencuci tangan anak kelas IV dan V

\begin{tabular}{|c|c|c|c|c|c|c|c|c|}
\hline \multirow[t]{3}{*}{ N0 } & \multirow[t]{3}{*}{ Variabel } & \multicolumn{4}{|c|}{ Keterampilan cuci tangan } & & & \multirow{3}{*}{$\begin{array}{l}P \\
\text { value }\end{array}$} \\
\hline & & \multicolumn{2}{|c|}{ Terampil } & \multicolumn{2}{|c|}{$\begin{array}{l}\text { Tidak } \\
\text { terampil }\end{array}$} & \multicolumn{2}{|c|}{ Jumlah } & \\
\hline & & $\mathrm{N}$ & $\%$ & $\mathrm{~N}$ & $\%$ & $\mathrm{~N}$ & $\%$ & \\
\hline \multirow[t]{4}{*}{1.} & $\begin{array}{l}\text { Dukungan } \\
\text { teman sebaya }\end{array}$ & & & & & & & \\
\hline & Tinggi & 18 & 66,7 & 9 & 33,3 & 27 & 100 & 0,370 \\
\hline & Rendah & 6 & 42,2 & 7 & 53,8 & 13 & 100 & \\
\hline & Jumlah & 24 & & 16 & & 40 & & \\
\hline & $\begin{array}{l}\text { Peran } \\
\text { petugas } \\
\text { kesehatan }\end{array}$ & & & & & & & \\
\hline & Tinggi & 15 & 65,2 & 8 & 34,8 & 23 & 100 & 0,209 \\
\hline & Rendah & 9 & 52,9 & 8 & 47,1 & 17 & 100 & \\
\hline & Jumlah & 24 & & 16 & & 40 & & \\
\hline \multicolumn{9}{|c|}{$\begin{array}{l}\text { 3. Peran orang } \\
\text { tua }\end{array}$} \\
\hline & Tinggi & 20 & 64,5 & 11 & 35,6 & 31 & 100 & 0,441 \\
\hline & Rendah & 4 & 44,4 & 5 & 55,5 & 9 & 100 & \\
\hline & Jumlah & 24 & & 16 & & 40 & & \\
\hline \multicolumn{9}{|c|}{ 4. Peran guru } \\
\hline & Tinggi & 23 & 67,6 & 11 & 32,4 & 34 & 100 & 0,029 \\
\hline & Rendah & 1 & 16,7 & 5 & 83,3 & 6 & 100 & \\
\hline & POR & 10,4 & & & & & & \\
\hline & Jumlah & 24 & & 16 & & 40 & & \\
\hline
\end{tabular}

Dari hasil uji statistik didapatkan $P_{\text {value }}=$ 0,370 lebih besar dari $\alpha=0,05$, hal ini menunjukkan bahwa tidak ada hubungan dukungan teman sebaya dengan keterampilan mencuci tangan pada anak kelas IV dan $\mathrm{V}$ SDN 179 Kota Pekanbaru.

Dari hasil uji statistik didapatkan $P_{\text {value }}=$ 0,209 lebih besar dari $\alpha=0,05$, hal ini menunjukkan bahwa tidak ada hubungan antara peran petugas kesehatan dengan keterampilan mencuci tangan pada anak kelas IV dan V SDN 179 Kota Pekanbaru. 
Dari hasil uji statistik didapatkan $P_{\text {value }}=$ 0,029 lebih besar dari $\alpha=0,05$, hal ini menunjukkan bahwa ada hubungan antara peran guru dengan keterampilan mencuci tangan pada anak kelas IV dan V SDN 179 Kota Pekanbaru. Hasil P OR menunjukkan bahwa siswa yang memiliki peran guru dalam kategori tinggi berkesempatan 10,445 kali

\section{PEMBAHASAN}

\section{Analisa Univariat}

\section{Usia}

Berdasarkan hasil penelitian yang dilakukan bahwa dari keseluruhan jumlah siswa/siswi kelas IV dan V SDN 179 Kota Pekanbaru yaitu sebanyak 211. Diambil sampel sebanyak 40 siswa. Karakteristik usia yang dipaparkan dapat disimpulkan bahwa nilai tengah usia responden (median) berusia 10,00 tahun. Rentang usia 9-12 adalah rentang usia yang ada di sekolah dasar Negeri 179 Kota Pekanbaru.

Pada masa anak usia sekolah yakni 6-12 tahun perkembangan yang terjadi anak menjadi lebih baik dalam berbagai hal misalnya mereka dapat berlari lebih cepat dan lebih jauh sesuai dengan perkembangan dan daya tahannya. Langkah perkembangan selama anak mengembangkan kompetensi dalam keterampilan fisik, kognitif, dan psikososial. Sekolah atau pengalaman pendidikan akan memperluas dunia anak dan merupakan salah satu transisi dari kehidupan yang bebas bermain ke kehidupan dengan lebih besar untuk terampil dalam cuci tangan dengan rentang 1,0 hingga 100,5.

Dari hasil uji statistik didapatkan $P_{\text {value }}=$ 0,441 lebih besar dari $\alpha=0,05$, hal ini menunjukkan bahwa tidak ada hubungan antara peran orang tua kesehatan dengan keterampilan mencuci tangan pada anak kelas IV dan V SDN 179 Kota Pekanbaru. bermain, belajar, dan berkerja yang terstruktur. Sekolah dan rumah yang mempengaruhi pertumbuhan dan perkembangan membutuhkan penyesuian antara orang tua dan anak, anak harus belajar menghadapi peraturan dan harapan yang di tuntut oleh sekolah dan teman sebaya (Potter \& Perry, 2009). Dalam hal ini pada usia sekolah ini anak telah mampu untuk menghadapi peraturan atau dapat membedakan mana yang baik dan tidak terutama dalam hal mencuci tangan dan anak harus dapat membuat keputusan dan menerima tanggung jawab.

Hasil penelitian ini sejalan dengan penelitian Mukminah, Istiati dan Syamsulhuda (2016) yang menjelaskan bahwa usia anak sekolah kelas IV dan V pada SD di wilayah puskesmas Banyuurip Purworejo yang menjelaskan bahwa umur responden kategori lebih muda (9-10 tahun) sebesar $18,1 \%$ dan anak-anak yang lebih tua (11-12) sebesar 81,9\%. dapat disimpulkan bahwa anak yang memliki usia 9-12 tahun telah mampu untuk membuat keputusan dan 
Oldhi Hanafi, Siska Mayang Sari, Abdurrahman Hamid,Faktor - Faktor yang Berhubungan dengan Keterampilan Cuci Tangan pada Anak Kelas IV dan V di SDN 179 Kecamatan Rumbai Kota Pekanbaru

sudah mulai bertanggung jawab terhadap perilakunya sendiri.

\section{Jenis kelamin}

Berdasarkan hasil penelitian yang telah dilakukan bahwa distribusi frekuensi karakteristik responden yaitu, mayoritas responden berjenis kelamin perempuan yaitu sebanyak $22(55,0 \%)$ responden. Hasil penelitian ini sejalan dengan penelitian Kartika, Widagdo, dan Shugiantono (2016) yang menjelaskan bahwa mayoritas responden berjenis kelamin perempuan yaitu 55,0\%. Hal ini didukung oleh penelitian Rosyidah (2014) tentang hubungan perilaku cuci tangan terhadap kejadian diare pada siswa di sekolah dasar negeri Ciputat 02 menunjukkan bahwa siswa terbanyak adalah berjenis kelamin perempuan yaitu sebnyak 32 orang $(57,1 \%)$. Dapat disimpulkan bahwa jenis kelamin anak sekolah dasar mayoritas berjenis kelamin perempuan. Pada dasarnya memang ada perbedaan gender dalam kemampuan mental dan kepribadian.

Anak perempuan lebih unggul dalam perkembangan bahasa namun lebih sensitif dan tergantung. Sedangkan anak laki-laki unggul dalam kemampuan keuangan dan lebih agresif. Namun dalam cara belajar anak perempuan dan laki-laki belajar melelui meniru atau mengamati lingkungannya, misalnya dengan memperhatikan apa yang dilakukan dan dikatakan orang. Melalui orang tua anak belajar mengenai peran gender, itulah sebabnya orang tua dikatakan sebagai sosok yang paling berpengaruh dalam perkembangan gender. Sementara kebudayaan, sekolah, kelompok sebaya, media masa, dan anggota keluarga lainnya merupakn sosok lainnya dimana anak bias belajar peran gender (Santrock, 2011). Dalam artian anak perempuan dan laki-laki memiliki cara yang sama dalam meniru terutama terhadap keterampilan mencuci tangan. Hal ini dapat dibuktikan bahwa jumlah anak lakilaki dan perempuan yang terampil dalam cuci tangan memiliki jumlah yang sama yaitu sebanyak 12 orang.

\section{Analisa Bivariat}

1. Hubungan dukungan teman sebaya dengan keterampilan mencuci tangan anak kelas IV dan V SDN 179 Kota Pekanbaru Berdasarkan hasil uji chi-square didapatkan $P_{\text {value }}=0,370$ lebih besar dari $\alpha=$ 0,05 , hal ini menunjukkan bahwa tidak terdapat hubungan antara dukungan teman sebaya dengan keterampilan mencuci tangan pada anak kelas IV dan V SDN 179 Kota Pekanbaru.

Interaksi teman sebaya dari kebanyakan anak usia sekolah ini terjadi dalam kelompok, sehingga periode ini sering disebut "usia kelompok". Pada masa ini, anak tidak lagi puas bermain sendirian dirumah, atau melakukan kegiatan-kegiatan dengan anggota keluarga. Hubungan pertemanan menjadi sebuah media pembelajaran dan pelatihan berbagai keterampilan sosial seperti negosiasi, 
persuasif, kerjasama, kompromi, kendali emosional dan penyelesaian konflik. Teman sebaya memberikan dukungan sosial, moral, dan emosional. Pengaruh teman sebaya tidak hanya berdampak positif akan tetapi juga berdampak negatif sehingga peran keluarga disini masih diperlukan ketika anak memilik teman (Santrock, 2011).

Berdasarkan penelitian Mukminah, Istiarti dan Syamsulhuda (2016) menjelaskan bahwa dukungan teman sebaya termasuk salah satu faktor yang sangat mempengaruhi perilaku mencuci tangan pakai sabun. Dukungan teman sebaya biasanya diberikan dalam bentuk ajakan dan melakukan cuci tangan bersama-sama. Namun tidak semua anak yang memiliki pengaruh teman terhadap perilaku mencuci tangan pakai sabun. Dapat disimpulkan bahwa sebagian besar siswa kelas IV dan $\mathrm{V}$ memiliki dukungan teman sebaya yang tinggi namun tidak semua siswa tersebut yang terampil dalam mencuci tangan. Oleh sebab itu tidak terdapat pengaruh antara dukungan teman sebaya terhadap keterampilan mencuci tangan.

2. Hubungan peran guru dengan keterampilan mencuci tangan anak kelas IV dan V SDN 179 Kota Pekanbaru.

Berdasarkan penelitian yang telah dilakukan dan didapatkan hasil uji statistik dengan menggunakan uji fisher's exact didapatkan didapatkan $P_{\text {value }}=0,029$ lebih besar dari $\alpha=0,05$, hal ini menunjukkan bahwa ada hubungan antara peran guru dengan keterampilan mencuci tangan pada anak kelas IV dan V SDN 179 Kota Pekanbaru.

Dalam proses belajar mengajar, guru tidak sekedar mengalihkan ilmu pengetahuan yang tekandung dalam kurikulum saja namun juga mengajarkan kerja sama, sikap empati, mau mendengarkan orang lain, menghargai, dan sikap lain yang dapat menimbulkan kecerdasan emosional (Effendi \& Makhfudli, 2009).

Menurut Desmita (2011), dalam upaya mencapai setiap tugas perkembangan anak maka guru dituntut dapat memberikan bantuan antara lain menciptakan lingkungan teman sebaya yang mengajarkan keterampilan fisik, melaksanakan pembelajaran yang memberikan kesempatan kepada siswa untuk belajar bergaul dan bekerja dengan teman sebaya, sehingga kepribadian sosial anak dapat berkembang, mengembangkan kegiatan pembelajaran yang memberikan pengalaman yang nyata atau langsung dalam membangun konsep, melaksanakan pembelajaran yang dapat mengembangkan nilai-nilai, sehingga siswa mampu menentukan pilihan yang stabil dan menjadi pegangan untuk diri sendiri.

Penelitian ini sejalan dengan penelitan Murwaningsih (2016) yang menjelaskan bahwa terdapat hubungan yang signifikan antara peran guru dengan penerapan perilaku cuci tangan pakai sabun dan air mengalir di 
Oldhi Hanafi, Siska Mayang Sari, Abdurrahman Hamid,Faktor - Faktor yang Berhubungan dengan Keterampilan Cuci Tangan pada Anak Kelas IV dan V di SDN 179 Kecamatan Rumbai Kota Pekanbaru

SDN II Kota Karang Bandar Lampung. Dapat disimpulkan bahwa siswa kelas IV dan V telah memiliki peran guru yang tinggi sehingga mereka memiliki keterampilan dalam mencuci tangan yang baik. Oleh karena itu terdapat hubungan antara peran guru terhadap keterampilan mencuci tangan pada siswi kelas IV dan V.

3. Hubungan peran petugas kesehatan dengan keterampilan mencuci tangan anak kelas IV dan V SDN 179 Kota Pekanbaru.

Berdasarkan hasil uji chi-square didapatkan $P_{\text {value }}=0,209$ lebih besar dari $\alpha=$ 0,05, hal ini menunjukkan bahwa tidak ada hubungan antara peran petugas kesehatan dengan keterampilan mencuci tangan pada anak kelas IV dan V SDN 179 Kota Pekanbaru.

Upaya pelayanan kesehatan di sekolah harus lebih diutamakan pada upaya meningkatkan kesehatan dan upaya pencegahan penyakit terutama dilaksanakan melalui kegiatan penjaringan kesehatan siswa kelas satu atau baru masuk sekolah, pemeriksaan berkala seluruh siswa, penyuluhan kesehatan dan imunisai. Sebagai penyuluh dalam bidang kesehatan, peran perawat kesehatan dalam memberikan penyuluhan kesehatan dapat dilakukan secara langsung seperti melalui penyuluhan kesehatan yang bersifat umum dan klasikal atau dapat dengan cara tidak langsung sewaktu melalukan pemeriksaan kesehatan peserta didik secara perseorangan. Petugas kesehatan yang selalu mensosialisasikan mengenai keterampilan cuci tangan maka keterampilan cuci tangan anak di sekolah pun akan menjadi semakin baik (Murwanto, 2017). Penelitian ini sejalan dengan penelitian Mukminah, Istiati dan Syamsulhuda (2016) yang menjelaskan bahwa tidak ada hubungan antara dukungan petugas kesehatan dengan praktik cuci tangan pakai sabun pada siswa SD di Wilayah kerja Puskesmas Banyuurip Purworejo.

Dapat disimpulkan bahwa masih banyak siswa yang memiliki peran petugas kesehatan yang tinggi namun masih banyak yang tidak terampil dalam mencuci tangan. Hal ini dapat disebabkan oleh beberapa hal, salah satunya adalah saat penyuluhan dilakukan oleh petugas kesehatan masih banyak siswa/siswi tidak mengerti akan penjelasan yang diberikan. Oleh karena itu tidak terdapat hubungan antara peran petugas kesehatan dengan keterampilan mencuci tangan siswa kelas IV dan V.

4. Hubungan peran orang tua dengan keterampilan mencuci tangan anak kelas IV dan V SDN 179 Kota Pekanbaru.

Berdasarkan hasil uji fisher's exact didapatkan $P_{\text {value }}=0,441$ lebih besar dari $\alpha=$ 0,05, hal ini menunjukkan bahwa tidak ada hubungan antara peran orang tua kesehatan dengan keterampilan mencuci tangan pada 
anak kelas IV dan V SDN 179 Kota Pekanbaru

Peran berarti perangkat tingkah atau karakter yang diharapkan atau dimiliki oleh orang yang berkedudukan dalam masyarakat, sedangkan peranan adalah tindakan yang dilakukan oleh seseorang dalam suatu peristiwa. Selain itu peran terutama ditentukan oleh ciri-ciri individual yang bersifat khas atau istimewa. Ayah sebagai suami dari istri dan anak-anak, berperanan sebagai pencari nafkah, pendidik, pelindung dan pemberi rasa aman, sebagai kepala keluarga, sebagai anggota dari kelompok sosialnya serta sebagai anggota masyarakat dari lingkungannya. Ayah juga berperan sebagai pengambil keputusan dalam keluarga. Sedangkan sebagai istri dan ibu dari anakanaknya, ibu mempunyai peranan untuk mengurus rumah tangga, sebagai pengasuh dan pendidik anak-anaknya, pelindung dan sebagai salah satu kelompok dari peranan sosialnya serta sebagai anggota masyarakat dari lingkungannya, disamping itu juga ibu dapat berperan sebagai pencari nafkah tambahan dalam keluarganya (Effendi \& Makhfudli, 2009).

Berdasarkan teori diatas, dapat kita simpulkan bahwa salah satu tugas orang tua adalah pengasuh dan pendidik bagi anak anaknya. Mengasuh dan mendidik anak dilakukan oleh orang tua dalam berbagai hal tidak hanya dari segi pendidikan, akan tetapi juga meliputi etika, sopan santun dan kebiasaan yang baik saat dirumah maupun diluar rumah. Membiasakan anak untuk mencuci tangan disaat sebelum makan, sesudah makan, setelah bermain dan lain sebagainya adalah bagian dari kebiasaan yang baik yang harus diterapkan oleh orang tua sedini mungkin serta hal ini adalah bagian dari mendidik anak. Apabila orang tua berhasil mendidik anak maka hal itu akan berpengaruh terhadap perilaku anak itu sendiri. Orang tua yang mendidik anaknya dan membiasakan anak untuk mencuci tangan tentu akan berpengaruh terhadap anak dimana anak tersebut akan biasa untuk mencuci tangan baik dirumah maupun diluar rumah.

Penelitian ini sejalan dengan penelitian Murwanto (2017) yang menjelaskan bahwa tidak ada hubungan antara peran orang tua terhadap perilaku cuci tangan pakai sabun. Dapat dismpulkan bahwa peran orang tua yang tinggi namun masih banyak siswa yang tidak terampil dalam mencuci tangan. Oleh karena itu tidak terdapat hubungan antara peran orang tua terhadap keterampilan anak dalam mencuci tangan.

\section{SIMPULAN}

Berdasarkan penelitian yang telah dilakukan oleh penliti di SDN 179 Kota Pekanbaru tentang faktor-faktor yang berhubungan dengan keterampilan cuci tangan. Hasil analisa bivariat menunjukkan variabel peran guru terdapat hubungan dengan keterampilan mencuci tangan. Untuk variebel 
Oldhi Hanafi, Siska Mayang Sari, Abdurrahman Hamid,Faktor - Faktor yang Berhubungan dengan Keterampilan Cuci Tangan pada Anak Kelas IV dan V di SDN 179 Kecamatan Rumbai Kota Pekanbaru

yang tidak berhubungan dengan keterampilan mencuci tangan yaitu dukungan teman sebaya, peran petugas kesehatan, peran orang tua.

\section{DAFTAR PUSTAKA}

Ariesandi, S. (2008). Rahasia mendidik anak agar sukses dan bahagia. Jakarta: Gramedia Pustaka Utama

Amelia, R. (2017). Analisis partisipasi kelas siswa laki-laki dan perempuan. Marwah: Jurnal Perempuan, Agama dan Jender, 16(1), 99-111. http://ejournal.uinsuska.ac.id/index.php/marwah/article/vie $\underline{w} / 4130$

Deperteman Kesehatan RI. (2008). Rumah Tangga Berprilaku Hidup Bersih Sehat. Naskah Publikasi

Desmita. (2011). Psikologi perkembangan peserta didik. Bandung: PT. Remaja Rosdakarya

Djauzi. S. (2009). Raih kembali kesehatan mencegah berbagai penyakit hidup sehat untuk keluarga. Jakarta: Kompas

Effendi, F \& Mukhfudlli. (2009). Keperawatan Komunitas: teori dan praktik. Jakarta: Salemba Medika

Idi, A. (2011). Sosiologi pendidikan individu, mayarakat dan pendidikan. Jakarta: PT. Rahagrasindo Perkasa

Kartika, M., Widagdo, L., \& Sugihantono, A. (2016). Faktor-Faktor yang Berhubungan dengan Perilaku Cuci Tangan Pakai Sabun pada Siswa Sekolah Dasar Negeri Sambiroto 01 Kota Semarang. Jurnal Kesehatan Masyarakat (e-Journal), 4(5), 339-346.

https://ejournal3.undip.ac.id/index.php/jk $\underline{\mathrm{m} / \text { article/view/14626 }}$

Kementrian Kesehatan Republik Indonesia.

(2016). Laporan kinerja ditjen kesehatan masyarakat tahun 2016. Jakarta

http://depkes.go.id/resources/download/L AKIP2017/5\%20LKj\%20Es\%201\%2020 16/3.\%20Laporan\%20Kinerja\%20Tahun \%202016\%20Ditjen\%20Kesmas.pdf

Kementrian Kesehatan RI. (2014). Perilaku mencuci tangan pakai sabun di

Indonesia.

http://www.depkes.go.id/download.php?f ile=download/pusdatin/infodatin/infodati n-ctps.pdf

Maryunani, A. (2013). Perilaku hidup bersih dan sehat (PHBS). Jakarta: CV. Trans Info Media

Mukminah, N., Istiarti, V. T., \& Syamsulhuda, B. M. (2016). Faktor Faktor yang Berhubungan dengan Praktik Cuci Tangan Pakai Sabun pada Siswa SD di Wilayah Kerja Puskesmas Banyuurip Purworejo. Jurnal Kesehatan Masyarakat (e-Journal), 4(5), 354-361. https://ejournal3.undip.ac.id/index.php/jk m/article/view/14628https://ejournal3.un dip.ac.id/index.php/jkm/article/view/1462 $\underline{8}$

Murwaningsih, S. (2016). Penerapan Cuci Tangan Pakai Sabun di SDN II Kota Karang Bandar Lampung. Jurnal Kesehatan, 7(1), 148-155. http://ejurnal.poltekkestjk.ac.id/index.php/JK/article/view/132

Murwanto, B. (2017). Faktor Perilaku Cuci Tangan Pakai Sabun (CTPS) di SMP. Jurnal Kesehatan, 8(2), 269-276. http://ejurnal.poltekkestjk.ac.id/index.php/JK/article/view/445

Nugroho, B. S., \& Fajriyah, N. (2014). Factors Associated with Implementation Handwashing in Third and Fourth Grades 21st State Elementary School in Talang Kelapa, District of Banyuasin in 2012. Jurnal Ilmu Kesehatan Masyarakat, 5(1), 71-76. https://media.neliti.com/media/publicatio ns/57992-ID-factors-associated-withimplementation-h.pdf

Potter, P. A., \& Perry, A. G. (2009). Fundamental keperawatan. Vol 1. Jakrta: Salemba Medika

Proverawati, \& Rahmawati, E. (2012). Perilaku hidup bersih dan sehat (PHBS). Yogyakarta: Nuha Medika

Rosyidah, A. N .(2014). tentang hubungan perilaku cuci tangan terhadap kejadian diare pada siswa di sekolah dasar negeri ciputat 02. Skripsi Publikasi 
Santrock, J. W. (2011). Masa perkembangan anak buku I Edisi-11. Jakarta : Salemba Humanika

World Health Organization. (2009). The world health organization guidelines on hand hygiene in health care. 